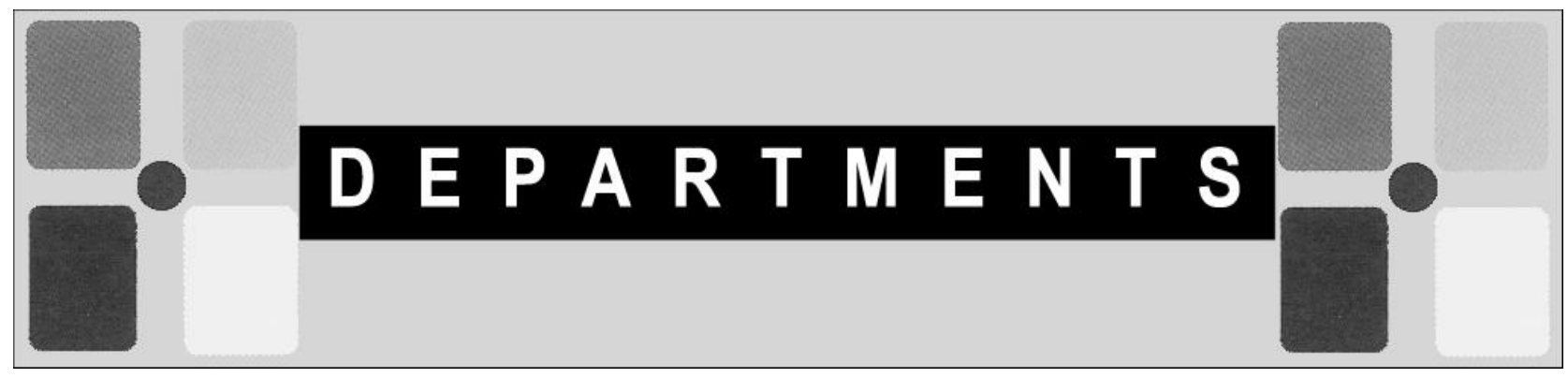

\title{
Resources on the Net: Multicultural Outreach
}

\author{
Compiled by Chris Bober, Concordia University, Montreal, Quebec
}

American Library Association. (2006). Office for Literacy and Outreach Services. Retrieved March 30, 2007, from http://www.ala.org/Template.cfm?Section=olos

The mission of the Office for Literacy and Outreach Services (OLOS) is to provide support to "traditionally underserved populations, including new and non-readers, people geographically isolated, people with disabilities, rural and urban poor people, and people generally discriminated against based on race, ethnicity, sexual orientation, age, language and social class." The Office supports its mission through various training, information resources, and technical assistance initiatives.

Association of College and Research Libraries Instruction Section. (2007, April 5). Research Agenda for Library Instruction and Information Literacy. Retrieved March 31, 2007, from http://www.ala.org/ ala/acrlbucket/is/iscommittees/webpages/research/researchagendalibrary.htm

This document is an updated version of The Research Agenda for Bibliographic Instruction, originally published by the ACRL Bibliographic Instruction Section (BIS) Research Committee in April 1980. It was revised to reflect the diverse ages, ethnicities, and abilities of the student populations that are served by instruction and information literacy programs. It was revised with the recognition that each of these diverse groups "presents unique issues for library instruction and information literacy programs."

Association of College and Research Libraries. Instruction for Diverse Populations Committee. (2003, December 2). Library Instruction for Diverse Populations Bibliography. Retrieved March 31, 2007, from http://www.ala.org/ala/acrlbucket/is/publicationsacrl/IDPbibliography.pdf

The Bibliography was created to meet the demand by college and university librarian instructors for information and resources about teaching diverse populations. It includes ten to twenty resources per specific population group: African Americans, Asian Americans, and Native Americans. The Bibliography includes both print and electronic resources so that librarians "needing to teach a class to students of a particular group can turn to the relevant section of the bibliography, find an overview of issues and strategies relating to that population, and locate informational resources that will give them immediate help in preparing teaching methods and materials."

Espinal, Isabel. (2002, June). Multicultural Outreach in Academic Libraries. Retrieved March 31, 2007, from www.ala.org/ala/pio/campaign/academicresearch/academic multicultural.pdf 
This document summarizes in point form a paper that was presented at the American Library Association's Annual Conference in June, 2002. It includes practical tips and advice for academic libraries seeking to develop outreach programs. It also reviews successful academic outreach programs at the University of California at Berkeley and at the University of Massachusetts at Amherst.

International Children's Digital Library Foundation. (n.d.) International Children's Digital Library. Retrieved March 31, 2007, from http://www.childrenslibrary.org/index.shtml

The International Children's Digital Library (ICDL) is a research project funded primarily by the National Science Foundation, the Institute for Museum and Library Services, and by Microsoft. Its goal is to create a digital library of more than 10,000 books in at least 100 languages published from around the world. The titles are collected with the aim of "identifying materials that help children to understand the world around them and the global society in which they live." This virtual library "provides a supportive, safe environment for children who speak different languages and are from different cultures to come together using activities related to books in the ICDL as common ground."

National Education Association. (2006). Minority Community Outreach. Retrieved March 31, 2007, from http://www.nea.org/mco/index.html

The guiding principle behind the National Education Association's Minority Community Outreach is that "every child deserves a quality education—regardless of race or ethnicity." It strives to develop partnerships with ethnic minority communities and to strengthen existing partnerships. This site provides links to significant events and activities and summarizes research on some of the major issues affecting American public education like closing the achievement gaps of culturally and linguistically diverse students. Their goal is to "meet the needs of these children, support ethnic minority community commitment to public education, work collaboratively to improve the quality of their schools, and assure all children the education they need and deserve."

Walter, S. (2005, November). Instructional Outreach and Campus Diversity: Building Partnerships with Multicultural Student Services. Retrieved March 30, 2007, from: https://kuscholarworks.ku.edu/ dspace/handle/1808/741

This is a slide presentation of a paper presented in November 2005 at the annual meeting of the Academic Library Association of Ohio. It reports on a study conducted at Washington State University whose purpose was to identify opportunities for collaboration between the academic library and student services offices dedicated to providing services to students of color. It provides practical guidelines and identifies "a number of discrete approaches to providing more effective library resources and services to students of color within the framework both of liaison with academic departments and of co-curricular service frameworks."

WebJunction. (2007). Retrieved on March 30, 2007, from http://webjunction.org

WebJunction, launched at the Library of Congress in 2003, is a growing collection of best practices, case studies and resources to facilitate outreach to all types of libraries and organizations that support public access to information technology for underserved populations. It includes outreach services and curriculum materials for use with recent immigrants and for use with Tribal and First Nations communities. The Spanish Language Outreach Program is another important resource that is designed "to provide public library staff with skills and resources to reach out to Spanish speakers in their local communities and increase the number of Spanish speakers using public access computers in libraries across the U.S."

Compilers' note: Text that is enclosed within quotations marks has been taken directly from the source document.

Chris Bober is the Education Librarian at Concordia University Libraries.

Email: boberc@alcor.concordia.ca 